\title{
Working
}

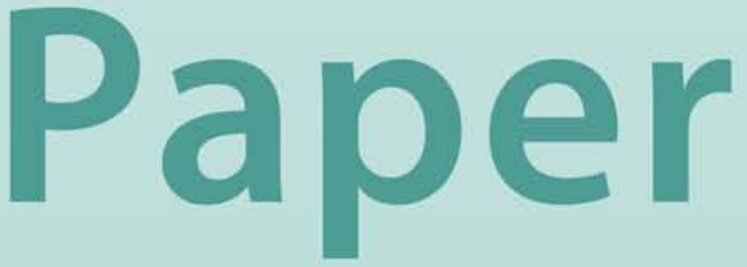




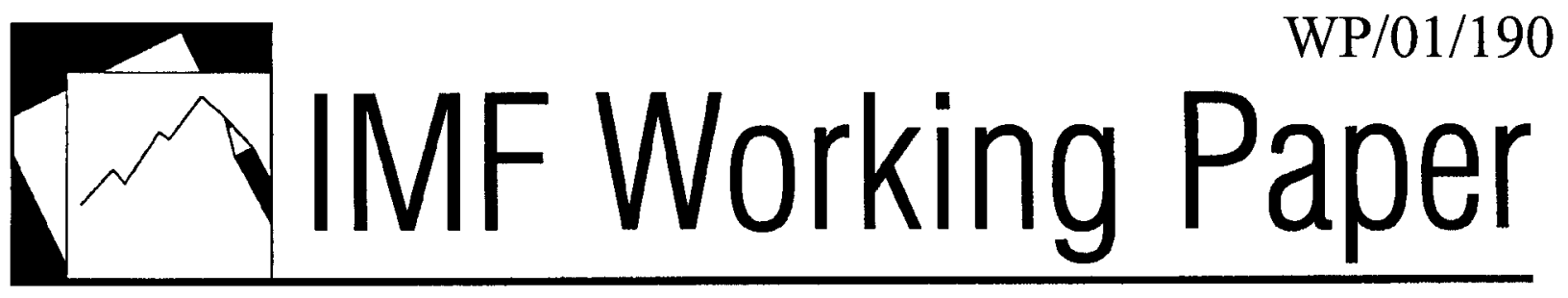

Exchange Rates and Capital Flows

Robin Brooks, Hali Edison, Manmohan Kumar, and Torsten Sløk 


\title{
IMF Working Paper
}

\author{
Research Department
}

\section{Exchange Rates and Capital Flows ${ }^{1}$}

Prepared by Robin Brooks, Hali Edison, Manmohan S. Kumar, and Torsten Sløk

Authorized for distribution by Kenneth Rogoff

November 2001

\begin{abstract}
The views expressed in this Working Paper are those of the author(s) and do not necessarily represent those of the IMF or IMF policy. Working Papers describe research in progress by the author(s) and are published to elicit comments and to further debate.
\end{abstract}

This paper explores the ability of portfolio and foreign direct investment flows to track movements in the euro and the yen against the dollar. Net portfolio flows from the euro area into U.S. stocks-possibly reflecting differences in expected productivity growth-track movements in the euro against the dollar closely. Net FDI flows, which capture the recent burst in cross-border M\&A activity, appear less important in tracking movements in the euro-dollar rate, possibly because many M\&A transactions consist of share swaps. Movements in the yen versus the dollar remain more closely tied to such conventional variables as the current account and interest differential.

JEL Classification Numbers: F31, F32

Keywords: exchange rate models, euro/dollar and yen/dollar exchange rates, capital flows Author's E-Mail Address:rbrooks2@imf.org; hedison@imf.org; mkumar@imf.org; tsloek@imf.org.

${ }^{1}$ A part of this work was used as input for Chapter 2 of the May 2001 World Economic Outlook. The authors thank Tamim Bayoumi, Menzie Chinn, Peter Clark, Albert Jaeger, Avinash Persaud, David Robinson, Ken Rogoff, Frank Warnock, and Alessandro Zanello for comments and suggestions and Yutong Li, Advin Pagtakhan, and Emily Conover for assistance. 


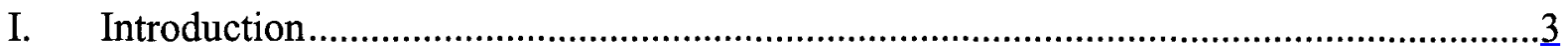

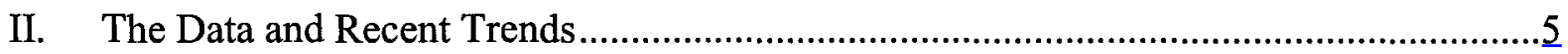

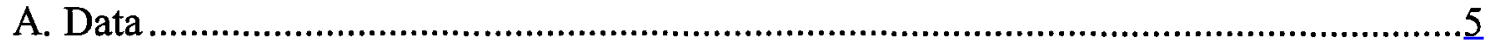

B. Evolution of Exchange Rates .....................................................................

C. Recent trends in Key Explanatory Variables .......................................................

Interest Rate Differentials ..........................................................................

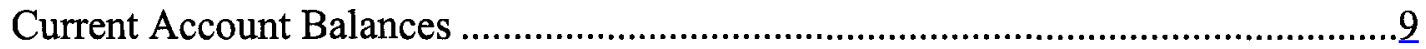

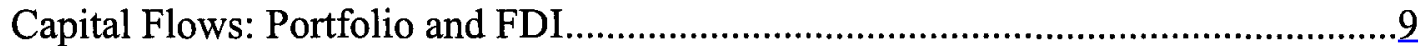

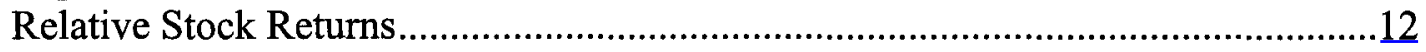

Expected Growth Differentials ..................................................................13

III. Empirical Analysis ........................................................................................ 15

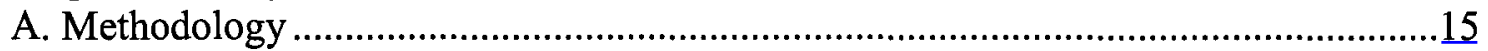

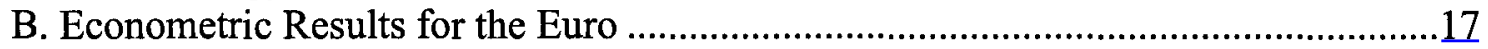

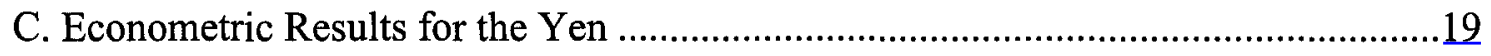

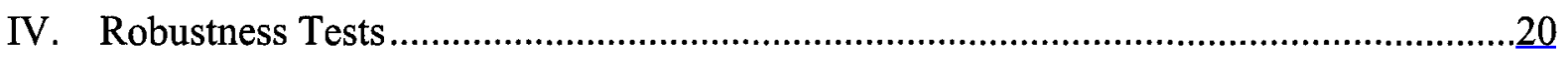

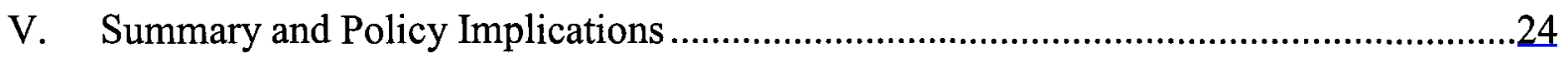

Tables:

1. Explaining Bilateral Exchange Rate Movements: Euro Area.....................................18

2. Explaining Bilateral Exchange Rate Movements: Japan ...........................................20

3. Explaining Bilateral Exchange Rate Movements: Germany and France......................21

4. Explaining Movements in the Multilateral Exchange Rate: Germany .........................22

5. Explaining Movements in the Multilateral Exchange Rate: Japan ...............................23

6. Bilateral Exchange Rate Movements and Expected Growth Differential

(US minus foreign)

Figures:

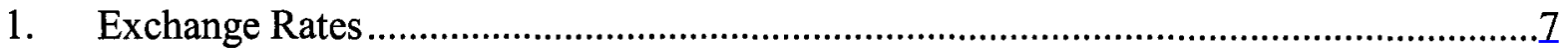

2. Bilateral Exchange Rates and Interest Rate Differentials ........................................

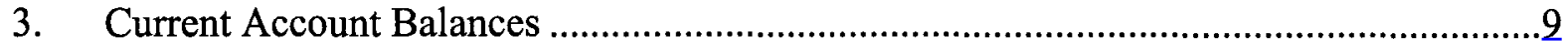

4. Global Net Portfolio Flows to the United States by Asset Class .................................11

5. Value of Cross-Border Mergers and Acquisitions...................................................12

6. Excess Returns on S\&P 500 over Eurostoxx and the Euro/U.S. Dollar

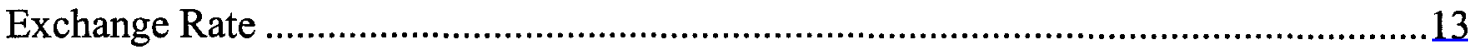

7. Forecast Growth Differential and Exchange Rate Between Euro and U.S. Dollar ........14 


\section{INTRODUCTION}

An important issue in international finance today relates to explaining the behavior of exchange rates among the three major currencies, especially over the past two years. ${ }^{2}$ From its introduction in January 1999 to end-August 2001, the euro fell against most major currencies - against the U.S. dollar, the Japanese yen and the British pound it fell 23,18, and 11 percent respectively, while in effective multilateral terms it declined by some 15 percent. Over the same period, the Japanese yen-despite its recent weakness-strengthened 5 percent in multilateral terms, but fell 6 percent against the dollar. The U.S. dollar continued to strengthen, with a gain of over 20 percent in effective terms since early 1999, and reached an almost 15 year high.

The behavior of the euro vis-à-vis the dollar and the yen is a particular puzzle. ${ }^{3}$ To the concern and bafflement of market analysts and policy makers alike the euro has fallen consistently even when the opposite was expected to occur. A key question remains how to reconcile the large and growing current account deficit of the United States with the persistent weakening of the euro. Similarly, how does one explain the weakness of the euro relative to the yen given that the Japanese economy was close to recession over this period with historically low nominal interest rates?

The widespread expectation in academia, policy circles, and markets was that the launch of a common currency in Europe would lead to its significant strengthening (see for instance Krugman 1998). The reasons for this expectation are well known. First, with the monetary union the economic potential of the euro area would begin to be realized, and productivity and potential growth rates would increase, attracting significant portfolio capital flows to the region. Second, direct investment flows would increase for similar reasons, as well as take advantage of the expanding markets. There had been a sharp increase in direct investment flows into the United Kingdom (from both the U.S. and Japan) in the early to mid-1990s, ostensibly to set up production facilities to serve European markets (see Kumar 1996). Expectations were such that there would be correspondingly greater inflows into the euro area Third, even without the first two considerations, globalization and integration of national financial markets continued apace and it was expected that there would be substantial net inflows into the euro area; and fourthly, there was expected to be a concerted move by central banks around the world to shift a substantial part of their foreign currency holdings into euro, both to benefit from the expected appreciation of the currency, and more generally to diversify into the currency of the second largest economic area in the world.

\footnotetext{
${ }^{2}$ See, for example, the discussion in Bailey, Millard, and Wells (2001) and Tille, Stoffels, and Gorbachev (2001).

${ }^{3}$ See, for instance, Aranda-Hassel et al (1999), Lehman Brothers (2000), and Goldman Sachs (2000) for a fairly representative sample of the private sector commentary and analysis relating to this issue.
} 
Some observers noted, however, that the ECB, as a new institution, would have to establish its credibility and reputation (see Goldman Sachs 1998). In the process of doing so, the portfolio and direct flows into euro denominated assets may be somewhat restrained, and therefore in this transition period of credibility being established the euro may not be as strong as was generally anticipated. However, even these observers were concerned that the new currency may not be strong enough; rather that it would weaken significantly and remain so for a protracted period of time.

A key feature of the major currency markets over the last two years has been the pronounced weakness in the euro, particularly against the U.S. dollar. As discussed below, this weakness seems to have defied "traditional" explanations of exchange rate determination, which focus on interest rate differentials and external current account imbalances. For instance, over the last two years interest rate differentials moved in favor of the euro in many instances, but successive hikes of short-term rates by the ECB were often associated with aggravating euro weakness, rather than strengthening it. In addition, the euro continued to weaken while the dollar strengthened despite the movement in the relative current accounts - the euro area current account has moved into surplus, while the U.S. current account deficit has grown.

The inability of traditional factors to explain the movements in the euro has led to consideration of alternative explanations. In particular, many market commentators have pointed to differences in relative output and corporate earnings growth rates between the euro area and the United States and associated capital flows as possibly an important element of the explanation. As was seen in the recent Asian crisis and the Mexican crisis in 1994-95, large capital movements can have a significant impact on the value of a currency. It does not, however, imply that these capital flows provide the only explanation for movements in a currency. Rather, capital flows can complement or supplement the traditional explanations. There are examples, as is currently the case for the Japanese yen, when capital flows do not seem to play an important role.

This paper examines movements of euro and yen against the dollar using both traditional and alternative explanations. The paper analyses in a systematic manner the role that capital flows played in these exchange rate developments from the perspective of the 1990s. The paper is organized as follows: Section 2 provides a brief description of the data, and then considers at some length the trends in major bilateral exchange rates and the ex ante expectations as well as bilateral capital flows. Section 3 presents the empirical results and section 4 augments those results with a series of robustness tests, including tests on multilateral capital flows. Section 5 presents the conclusions and policy implications.

Anticipating the results, a key finding of the paper is that exchange rate movements may be becoming more sensitive to equity portfolio capital flows relative to current account transactions, although interest rate differentials continue to matter. Capital flows in turn reflect a desire for portfolio diversification, as well as expectations of changing relative rates of return. Going forward, whether these expectations turn out to be relatively stable, and the 
impact changes in these expectations will have on portfolio flows, will determine the speed and extent of any pronounced changes in the constellation of major currency exchange rates.

This paper complements the recent study by Meredith (2001) which utilizes detailed model simulations to show that the stock market boom associated with the New Economy provides an important explanation for the weakness of the euro. Although the surge in equity prices had been global, Meredith (op.cit.) argues that demand in the US was disproportionately affected, because new economy sectors are bigger than in Europe, overall market capitalization is higher, and stock ownership is more pervasive. Therefore, even with a decline in the equity premium that is broadly equal across the US and Europe, the positive impact on demand in the US is greater because the stock market is of greater relevance to the economy than in Europe.

\section{The Data ANd ReCEnt TRENDS}

This section provides an overview of the data utilized in the empirical analysis, in particular trends in the exchange rates and some of the explanatory variables.

\section{A. Data}

The empirical analysis in this paper is based largely on bilateral exchange rates of the euro and Japanese yen vis-à-vis the U.S. dollar, and corresponding bilateral data on current accounts of the balance of payments, measures of economic activity, capital flows, and asset returns for the Euro area and Japan relative to the United States. Some robustness checks using multilateral data were also undertaken, and the results were in general consistent with those reported for the bilateral rates.

Although in theory it would be desirable to undertake more extensive analysis on a multilateral basis, or perhaps even limit the analysis to multilateral rates, the reasons for preferring analysis on a bilateral basis were threefold: first, most of the public concerns and policy issues appear to be related to the value of the euro vis-à-vis the dollar, and to a limited extent its value against the yen, rather than its multilateral value; in the case of the Japanese yen also, the main focus has been on its relationship with the dollar. Second, the values of multilateral rates depend importantly on the weights used, which are generally not current. For instance, in the Information Network System (INS) of the IMF, the multilateral rates are computed on trade data based on the early to mid-1990s. To the extent that there has been a change in trade patterns in recent years, partly anticipating and reflecting the formation of the euro area, this may not provide an accurate description of the underlying movements in the constituent exchange rates. Third, the data on the main explanatory variables is likely to have less noise on a bilateral basis: for instance, one of the key hypotheses examined below is the extent to which equity returns in the euro area relative to those in the U.S. were a determining factor for the net capital flows between the two, and in turn had a significant impact on the bilateral exchange rate. One could readily construct euro area returns vis-à-vis 
the rest of the world, but the results are likely to have considerable noise, and may be less revealing.

Three features of the dataset are worth highlighting. First, in order to have a sufficiently long time series, and test for structural breaks, a "synthetic" value of the euro was utilized, based on the values of the constituent currencies, extended back to January 1990, allowing analysis of the euro/dollar rate over the period 1988Q1 to 2000Q3. To assess whether the use of the "synthetic" euro could lead to biases, analysis using the deutsche mark/dollar rate was also undertaken. The results were somewhat weaker compared to those for the euro/dollar rate but qualitatively similar. For Japan, the analysis was also undertaken for the period $1988 \mathrm{Q} 1$ to $2000 \mathrm{Q} 3$.

Second, in order to abstract from excessive noise in the monthly data, most of the analysis utilized quarterly data, averaged over each quarter. Nevertheless, to the extent that more current monthly data were available, tests using monthly data were also undertaken, and provided somewhat similar results. We also experimented with end-of period data, but given that capital flows were for the duration of each period, it is more appropriate to use averages for the periods.

Finally, in order to ensure data comparability across countries care was taken in putting together the dataset. For example, for the euro area as well as Japan and the U.S. three sets of equity price indices were obtained to compute comparable relative returns: these included a broad measure such as S\&P 500, Topix, and EUSTXX for the U.S., Japan and the euro area respectively; a narrow measure essentially composed of blue-chip companies such as Dow Jones Index, Nikkei 225, and EUSTXX50; and a technology dominated index such as the Nasdaq, Topixht, and Estxht. There are significant differences in returns based on these different indices in the short run as well over the medium and long run. In the case of short-term interest rates, data were standardized to provide three-month returns; bond yields are for comparable ten-year maturities.

\section{B. Evolution of Exchange Rates}

Figure 1 shows the movement in bilateral and nominal effective exchange rates since 1988. The euro has fallen almost monotonically against the U.S. dollar and in effective terms since its inception on January 1, 1999, depreciating by some 25 and 20 percent, respectively. It fell below parity with the dollar in the fourth quarter of 1999 to a level that was the lowest for the Euro area currencies since the beginning of the 1990s, and subsequent to that, it continued to depreciate further. The euro gained some ground in late 2000 and early this year, but in recent months has again traded near historic lows. Until recently, the euro also depreciated against the Japanese yen, underlining its broad-based weakness.

The Japanese yen, following a significant correction from its peak in the spring of 1995 to mid-1998, rose both against the dollar and in multilateral terms during 1999, and in the first quarter of 2000. It traded in a relatively narrow range in the following three-quarters or so, before weakening appreciably in the last six months The U.S. dollar continued to 
Figure 1. Exchange Rates
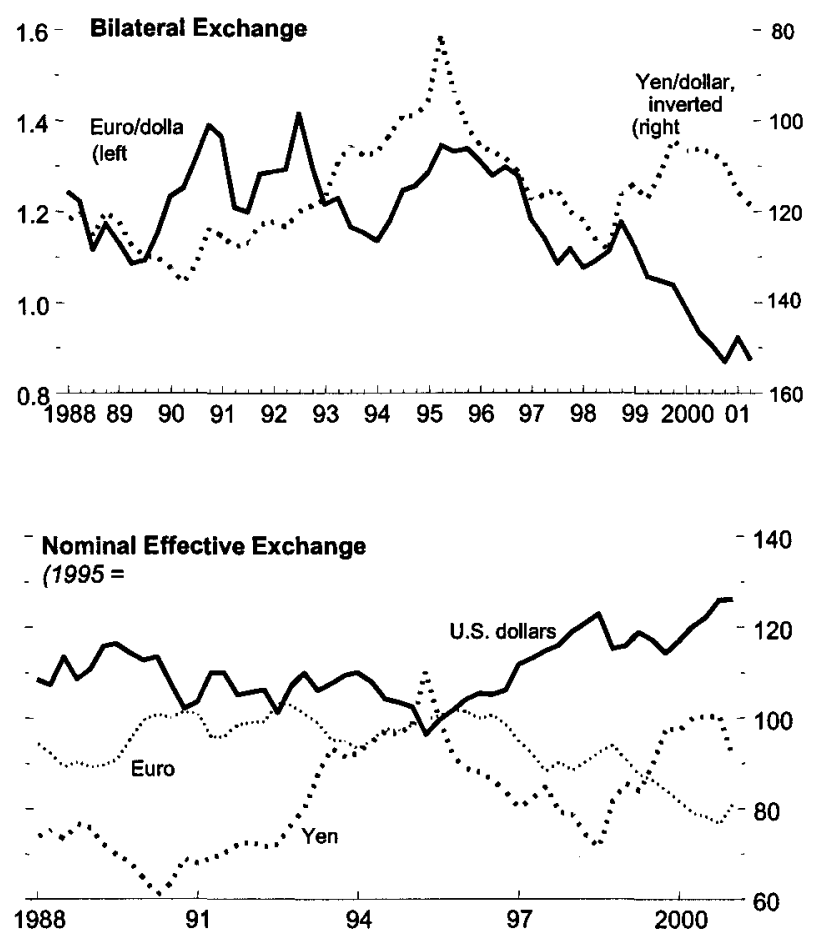

strengthen in nominal effective terms until late last year, reaching near record levels in effective terms, and vis-à-vis the euro. Since the beginning of the year, even with clear indications that economic activity was weakening, the dollar has moved mostly sideways.

\section{Recent Trends in Key Explanatory Variables}

This section examines the behavior of some of the key explanatory variables. Interest rate differentials, the mainstay of the rationale for the dollar's strong values in the early to mid-1980s, while favoring the dollar to some extent, have been considered to be only a partial, and not a particularly important, explanation. ${ }^{4}$ Rather, the strength of the dollar in recent years, despite a record and mounting external current account imbalance, has been explained mainly in terms of an increase in productivity growth and the underlying potential of the U.S. economy. The associated variables with this explanation include: capital flows, stock returns, and relative growth expectations, which are discussed in turn below.

\footnotetext{
${ }^{4}$ See Krugman (1988) who argued that the high value of the dollar in 1985 reflected the differential in interest rates between the United States and other industrial countries of around 3-4 percentage points.
} 


\section{Interest Rate Differentials}

Figure 2 shows the movement of short-term and long-term interest differentials. Since 1999 the relationship between interest rate differentials and exchange rates has gone counter to what is normally expected. In particular, the relationship between the euro/dollar exchange rate and the spread between government bond yields in the euro area and in the United States has changed. The two variables followed each other closely until the end of 2000 when the interest rate differential turned in favor of the US dollar and the US dollar continued to appreciate versus the euro. The relative interest rate movements for the yen show a higher correlation in the later part of the sample than in the beginning part of the sample as the yen strengthened against the dollar.

Figure 2. Bilateral Exchange Rates and Interest Rate Differentials
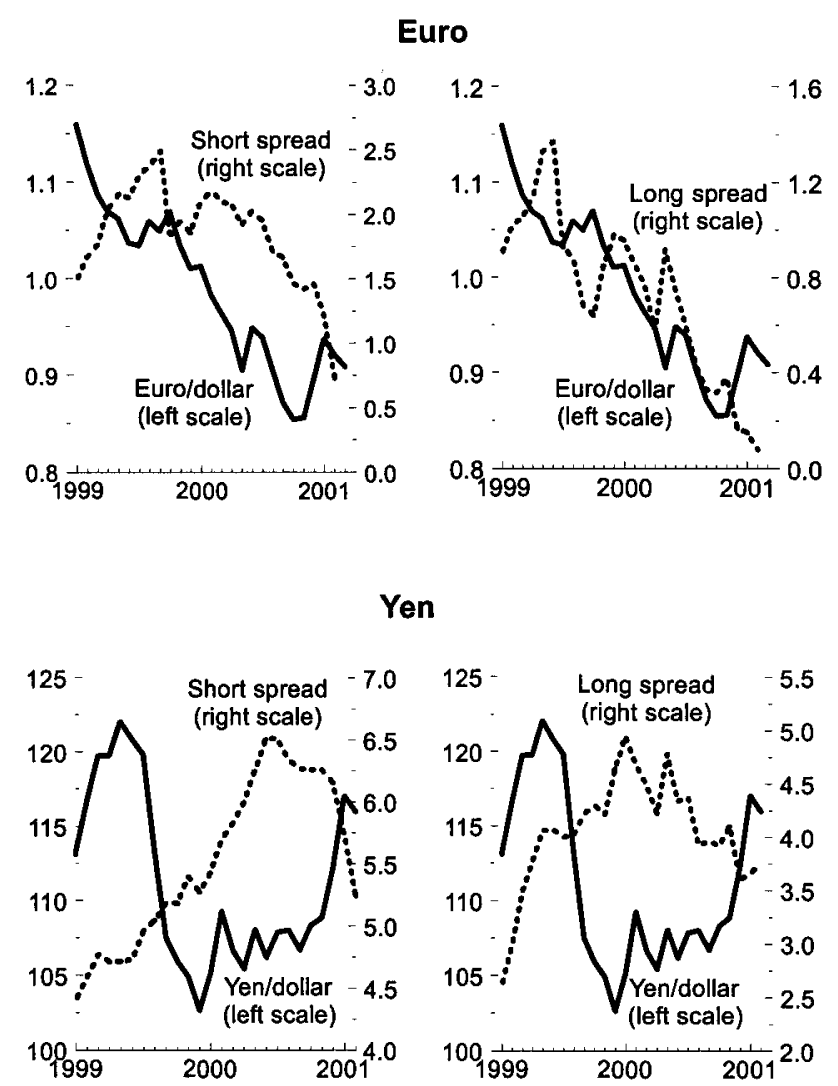


\section{Current Account Balances}

Figure 3 shows that there have been different current account developments across the three regions. The U.S. has experienced a large and growing overall current account deficit as well as rising bilateral current account deficits against both the euro area and Japan. Japan has had a large and relatively stable overall current account surplus in recent years (on the order of US $\$ 100$ billion per annum), while the current account of the euro area has deteriorated from a surplus of US $\$ 100$ billion in 1997 to a small deficit in 2000 . Given the need to finance these transactions through the capital account, the deterioration in the external balance of the United States might be expected to have created pressure for depreciation of the U.S. dollar.

Figure 3. Current Account Balances (Percent of GDP)

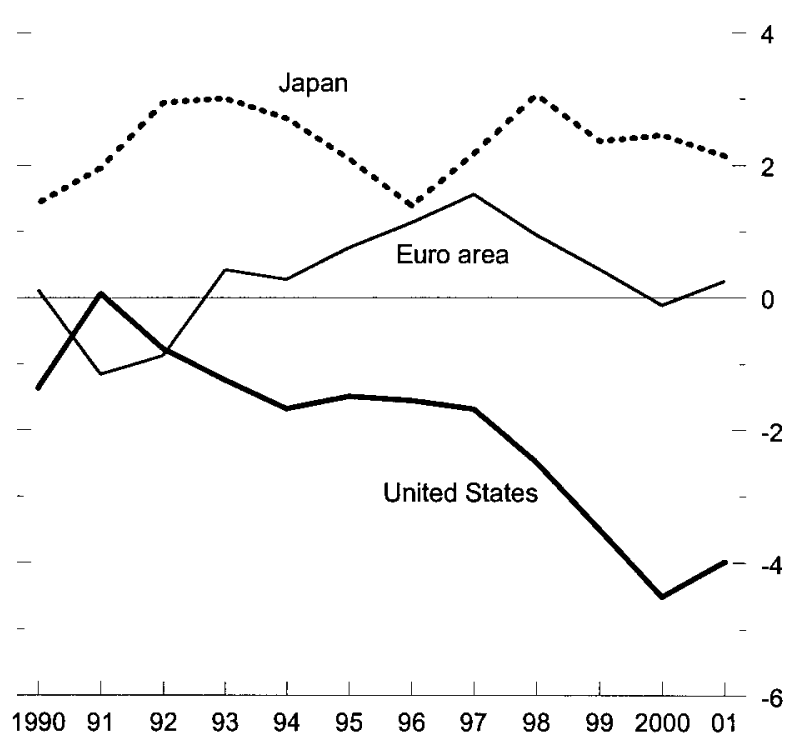

\section{Capital Flows: Portfolio and FDI}

Net portfolio flows into the U.S. increased significantly during the course of the 1990 s, with the dominant factor behind these flows associated with moves into and out of U.S. assets. ${ }^{5}$ Figure 4 illustrates the extent to which net portfolio flows into U.S. assets-U.S. government bonds and notes, agency bonds, corporate bonds and corporate stocks - have

${ }^{5}$ There are some instances where capital flows into foreign assets have been importantsuch as the move by U.S. investors into Japanese equities in 1999. 
bonds and notes, agency bonds, corporate bonds and corporate stocks-have grown. ${ }^{6}$ They have risen from low levels in the early 1990s to a peak in 1997 at US $\$ 388$ billion and have since stabilized around US $\$ 350$ billion in recent years. ${ }^{7}$

This striking growth in net inflows into U.S. assets has been accompanied by an important shift in the composition of these flows towards agency and corporate bonds as well as stocks, relative to government bonds and notes. Figure 4 shows that since 1995 global net flows into U.S. stocks have grown by a factor of 12 , flows into U.S. corporate bonds by a factor of 2 and flows into U.S. agency bonds by a factor of 4. Meanwhile, net flows into U.S. government bonds have contracted, turning negative in 1999 and beyond.

This shift in the composition of flows is even more pronounced comparing net flows into U.S. assets across regions. The middle panel of Figure 4 shows that net flows into U.S. equities have risen dramatically from the euro area, while there is little evidence of a similar shift for Japan (lower panel). The figure also shows that net flows into U.S. government bonds and notes from the euro zone have fallen significantly and even turned negative during the late 1990s, while they have remained positive and broadly unchanged for Japan. It should be noted though that there is a significant difference in magnitude comparing net flows to the U.S. from Japan with those from the euro area. Net flows from Japan are consistently smaller. In contrast to U.S. government bonds and notes, there is evidence of growing net flows across regions into other fixed-income assets such as corporate bonds and agency bonds. The shift towards agency bonds is especially pronounced for net flows from the euro zone

\footnotetext{
${ }^{6}$ Bilateral data on portfolio flows are based on the U.S. Treasury International Capital (TIC) reporting system and can be downloaded from http://www.treas.gov/tic/. The TIC data have a number of shortcomings. In particular they reflect only the location of the transaction before the United States so it is necessary to assume that the recorded transactions for a country are conducted for a domestic resident. While this assumption seems reasonable for flows from countries lacking large financial centers, it is more problematic for countries with such centers such as the U.K. or countries that have rapidly growing financial centers such as Germany. In addition, any transactions carried out through such a center-for example a German purchase of U.S. assets organized through London-will be recorded as a flow from the United Kingdom. Finally, the data for U.S. assets distinguish between government bonds, agency bonds, and corporate bonds, while foreign assets are only divided into bonds and equities.

${ }^{7}$ The data for the year 2000 covers only the first three-quarters.
} 
Figure 4. Global Net Portfolio Flows to the United States by Asset Class

(Billions of U.S. dollars)

U.S. Treasury and bond notes U.S. corporate bonds

U.S. government agency bonds U.S. equities

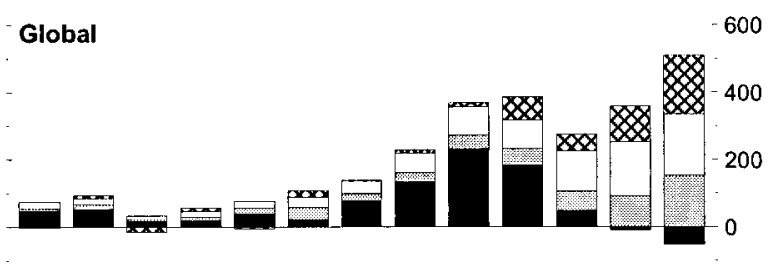

$\begin{array}{ccccccccccccc}1988 & 89 & 90 & 91 & 92 & 93 & 94 & 95 & 96 & 97 & 98 & 99 & 2000\end{array}-200$

$\begin{array}{ll}\text { Euro area } & -160\end{array}$

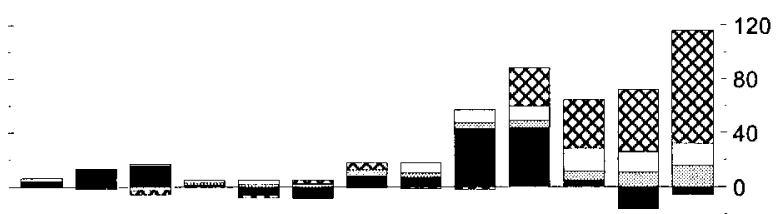

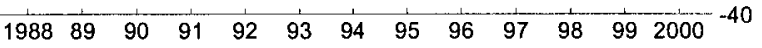

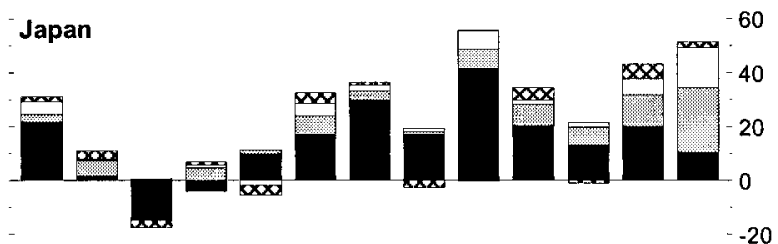

$\begin{array}{lllllllllllll}1988 & 89 & 90 & 91 & 92 & 93 & 94 & 95 & 96 & 97 & 98 & 99 & 2000\end{array}$

Source: U.S. Treasury Department. 
The rapid expansion in international equity flows has been accompanied by a boom in cross-border mergers and acquisitions (M\&A) flows. Figure 5 shows that these flows have grown significantly in recent years, rising from US\$278bn in 1997 to announced deals worth US\$ 1,200 billion in 2000. (Japan has not been a significant player in this area.) Several private analysts have pointed to these as an important element in explaining the path of the euro. However, there have been a number of skeptics that take the view that as most crossborder mergers are financed through share-swaps, they entail no immediate demand for currencies.

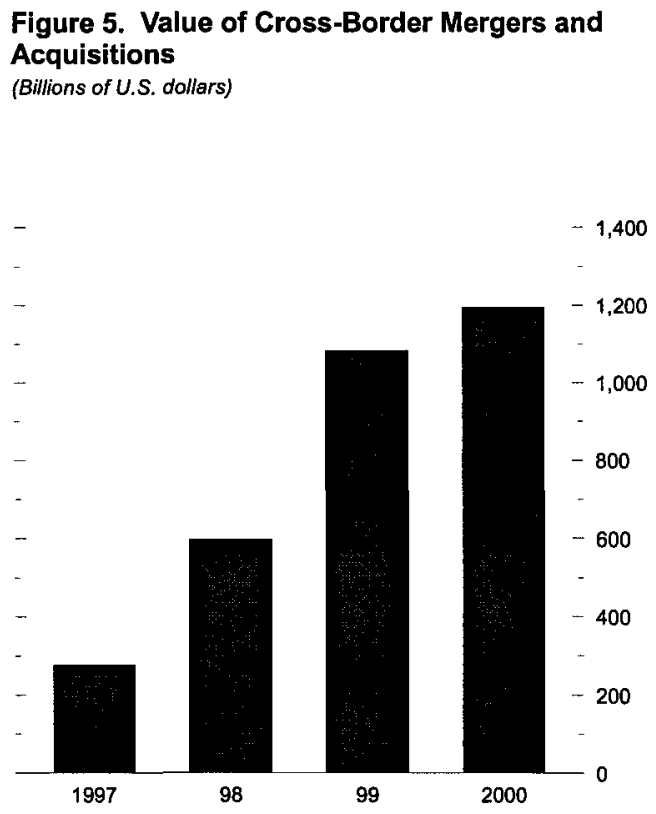

\section{Relative Stock Returns}

Intuitively, it would appear that the growing importance of net flows into US stocks from Euroland is related to higher expected stock returns in the US relative to Euroland. Figure 6 shows that there is little evidence to support this notion. Various measures of return differentials (S\&P500 versus Eurostoxx, etc.) fail to explain movements in the EUR/USD exchange rate successfully. There is however, evidence that the net flows into US equities from Euroland are closely correlated with the level of new economy stock prices, perhaps an indication that this is a better measure of investors' expectations. 


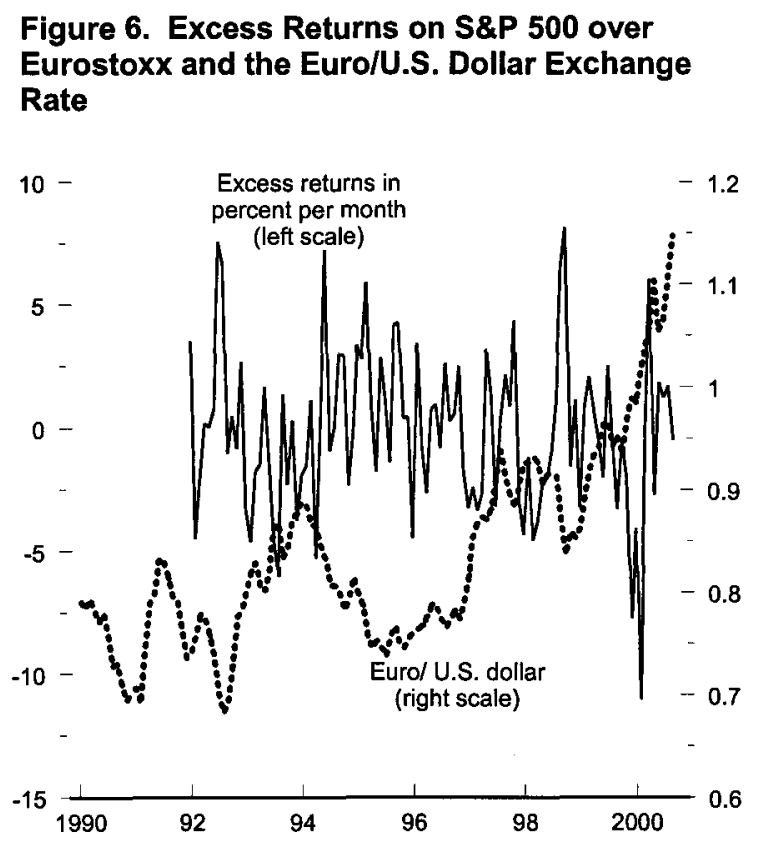

\section{Expected Growth Differentials}

Figure 7 suggest that there has been a high correlation between changes in the Consensus Forecast for growth and the euro/dollar rate. The left-hand panel indicates that as the differential between projected euro area and U.S. growth for 2000 widened during the course of 1999 and the first half of 2000, the euro fell almost pari passu. A similar pattern shown in the right-hand panel is observed for the projections for 2001, except that rather dramatically since the beginning of the year, as the projected differential in growth has swung in favor of the euro area, the euro itself has given back some of the gains it chalked up in the aftermath of the concerted intervention last September.

It should, however, be mentioned that the standard deviation around the average consensus forecasts increased significantly in 2000 . This was primarily due to the many uncertainties involved in the forecasting of US growth in the light of the fall in stock markets, particularly in technology stocks, from their peak in April 2000 and also in investment spending. ${ }^{8}$ Furthermore, in this environment the weakness of the euro was also based on the US dollar being the reserve currency of the world and consequently the perceived "safe haven" in case of global uncertainty.

\footnotetext{
${ }^{8}$ For studies of the impact of falls in technology and non-technology stock prices on consumption and investment, see Edison and Sløk (2001a and 2001b).
} 
Figure 7. Forecast Growth Differential and Exchange Rate Between Euro and U.S. Dollar
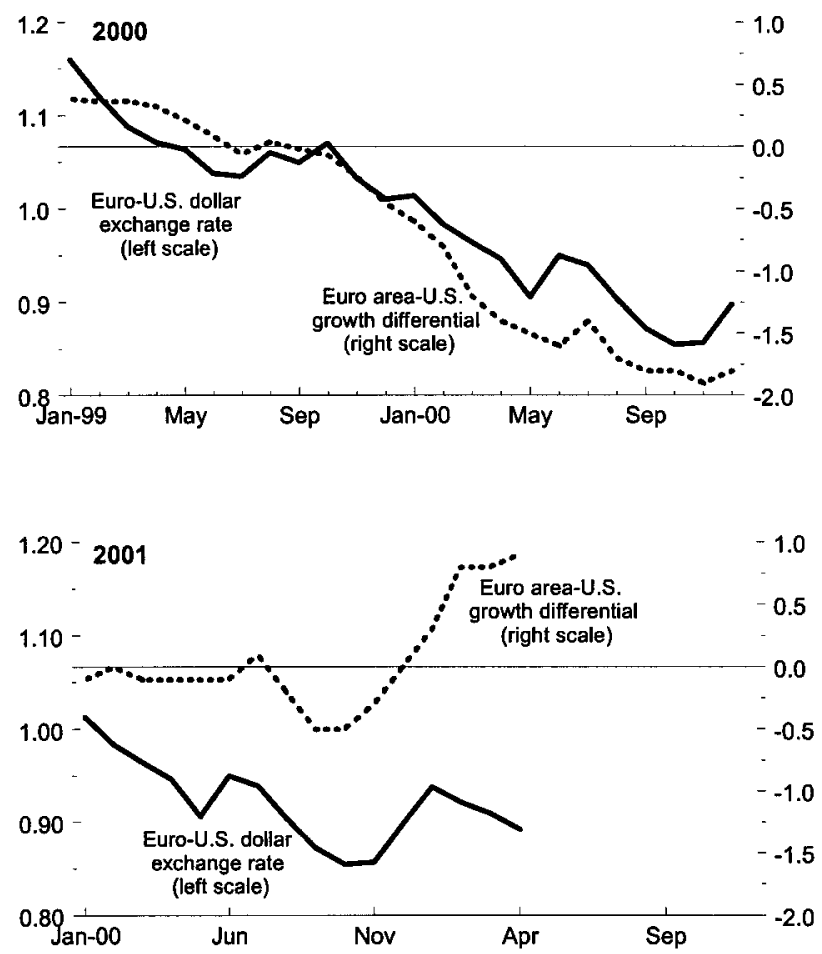

In terms of actual data rather than projections, the picture is complicated. In the third quarter of last year, when evidence began to trickle in questioning the sustainability of U.S. growth at above 5 percent levels, there was no marked improvement in sentiment in favor of the euro. Indeed, it was at that time that the euro fell to a record low leading to concerted intervention on its behalf. There was a small rebound in its value subsequently, but this gain was given back in early 2001, just as evidence mounted that the U.S. economic slowdown was likely to be deeper and faster than had been anticipated, and policy rates were cut (as of end-June 2001 ) by 275 basis points.

More recently, there has been some market concern that euro area monetary policy may be too tight, and that this in turn, by further weakening the growth prospects in the region, is having an adverse effect on the euro. (See, for instance, Aranda-Hassel et. al. 2001). Support for this proposition appears to be derived from considering high frequency (daily) data. For instance, on March 13, 2001, the euro posted a sharp fall against the dollar, ostensibly as a higher than expected outturn for February inflation in France and Germany 
raised concern that monetary policy would not be eased. ${ }^{9}$ To a considerable extent, this type of assessment appears to be ex-post rationalization of the continuing weakness of the currency.

If one takes a longer perspective for the euro based on the constituent currencies prior to 1999 , it is apparent that the weakness of the euro since its inception continued a decline, which had begun in the mid-1990s in the constituent currencies, both in effective terms as well as vis-à-vis the dollar. This earlier decline reflected to some extent weaker prospects and policy uncertainties in the major European countries, as well as uncertainty about the timing of the steps towards the monetary union itself. However, there was a widespread expectation, (as noted above), that the launch of a common currency would lead to its significant strengthening.

\section{EMPIRICAL ANALYSIS}

This section describes the empirical methodology and summarizes the econometric results, focusing on explaining the recent performance of the U.S. dollar vis-à-vis the euro and the yen.

\section{A. Methodology}

Much attention has been paid in the financial press about the possible link between capital flows into the United States and the dollar but there has been little empirical evidence published testing the hypothesis that currencies are as much influenced by capital flows as by current account balances and long-term interest rates. Traditional models of exchange rate determination have generally focused on interest differentials, relative inflation rates, and relative current account positions. ${ }^{10}$ For example, in the classic Mundell-Fleming open economy model, the interest differential drives capital flows that determine exchange rates. Although these models have been used extensively, their predictive power has been limited. ${ }^{11}$ Typically, the key variable has been the yield differential for long-term government bonds, which tends to explain less than a quarter of the movement in exchange rates.

This low explanatory power is in part due to the inherent nature of currency markets where a large number of factors impinge upon the outcome. But it is also possible that

\footnotetext{
${ }^{9}$ Waning expectations of monetary easing were clearly reflected in a sharp jump in the Euribor futures.

${ }^{10}$ For a description of the literature on exchange rate economics see Isard (1995) and Taylor (1995).
}

${ }^{11}$ See Meese and Rogoff (1983). 
exchange rate models need to be refocused to take into account different variables. The current focus of these models is implicitly on bond or debt flows, almost neglecting equity flows. As documented above, these flows have increased sharply over the last ten years and in some instances dwarfed fixed-income flows. Given the significant differences in the determinants of these flows compared with debt flows, it is at least arguable that they would have a differential impact on exchange rates. For instance, debt flows are typically hedged and hence their effects on exchange rates may be limited. Conversely, equity portfolio flows are generally not hedged and are therefore likely to have stronger influence on the currency markets.

The aim of our empirical work is to consider which factors are most useful in explaining recent exchange rate behavior. ${ }^{12}$ To assess the relative importance of each explanatory variable a statistical model was formulated. Specifically, the log change in the bilateral exchange rate (local currency per dollar) was regressed on a large set of explanatory variables sequentially. The explanatory variables are the U.S. bilateral current account balance and bilateral net bond flows (covering traditional explanations of exchange rate movements), bilateral net equity flows, and net foreign investment (for equity flow explanations of exchange rate movements). In addition, similar regressions are estimated for variables that might explain these flows. Current cyclical conditions, short-term interest rate differentials, and long-term interest differentials are used to investigate the validity of traditional explanations of exchange rate dynamics. Relative equity returns are also included to investigate the newer view that portfolio equity flows are important for exchange rates.

In general, it is not an easy task to model exchange rates and this task is complicated further by the short sample period since the introduction of the euro. To deal with the short sample problem, this study extends euro area data on the bilateral current account and various capital account flows back to the start of 1988 by aggregating data over the 11 current members of the euro area and calculating a corresponding synthetic version of the euro. ${ }^{13}$ To address the question whether the explanatory power of capital flows is strictly a European story, the yen-dollar exchange rate is also considered.

${ }^{12}$ Several explanations have been that attempts to explain the recent movement of the euro, see for instance, DeGrauwe (2000), Chinn and Alquist (2000), and Clostermann and Schnatz (2000).

${ }^{13}$ Data on the bilateral current account of the U.S. with respect to the European Union, Japan and the U.K. is available from the Bureau of Economic Analysis at http://www.bea.doc.gov. The bilateral current account data of the U.S. with the European Union represents an aggregate of 12 countries (Belgium, Denmark, France, Germany, Greece, Ireland, Italy, Luxembourg, the Netherlands, Portugal, Spain, United Kingdom) and does not correspond exactly to the current euro area. Nonetheless this aggregate was used to proxy for the euro zone. Bilateral data on net FDI flows into the U.S. is available from the same source. 


\section{B. Econometric Results for the Euro}

Table 1 contains the bivariate quarterly regression results for the euro, reporting the beta coefficients (and corresponding t-statistics) and the R-square statistics for three sample periods: 1988:1 to 1994:4, 1995:1 to 2000:3, and 1988:1 - 2000:3. The data start in 1988 to provide some perspective on whether changes may have occurred in the middle of the 1990s as a result of increases in capital flows between Europe and the United States. The general result that emerges is that net equity flows are important for explaining recent movement in the euro-dollar exchange rate.

Turning to the specific individual results, the first row gives the estimate for the bilateral current account. The coefficients on the current account are not statistically significant and the reported signs are negative, which is counter to the more conventional positive sign. The negative sign on the current account balance is, however, consistent with the productivity story, which suggests that a structural improvement in US productivity increased the rate of return on US capital, leading to a substantial increase in capital flows into the United States and the appreciation of the dollar.

The next row and the subsequent three rows report estimates for net bond flows and the sub-components of those flows. Many of the estimated coefficients are positive, but are not statistically significant. However, there are four coefficients that are statistically significant. In particular the coefficients on net bond flows and net government bond flows in the early sample period are significant and negative while the coefficients on agency bond flows, which have become more important over time, are positive and significant, especially for the period since 1995 .

Equity portfolio flows, like agency bond flows, increased dramatically in the mid1990s and the evidence in the table supports the notion that equity portfolio flows are positively correlated with movements in the euro-dollar exchange rate. In particular, the coefficient on net equity flows is significantly positive. While the rise in equity flows has been associated with the run-up in US equity values, when testing the correlation between relative equity returns and the exchange rate, all of the coefficients turned out to be negative and significant which is counter-intuitive.

In addition to increases in equity flows there has also been a sharp increase in crossborder mergers and acquisitions. To examine the extent to which these mergers have had an effect on the exchange rate, the role of U.S. bilateral foreign direct investments is considered. The coefficients are positive, but statistically insignificant. The lack of explanatory power of net FDI flows suggests that M\&A flows (which are incorporated in the FDI data) have not played an important role in the recent euro weakness. Indeed, the role of M\&A flows has been the subject of some controversy. Initially, several private sector analysts pointed to the size of M\&A flows as an important element in explaining the path of the euro against the dollar. Our results however are more consistent with a more skeptical view, which recognizes 
Table 1. Explaining Bilateral Exchange Rate Movements: Euro Area

\begin{tabular}{|c|c|c|c|c|c|c|}
\hline & \multicolumn{2}{|c|}{ 1988:1-1994:4 } & \multicolumn{2}{|c|}{ 1995:1-2000:4 } & \multicolumn{2}{|c|}{ 1988:1-2000:4 } \\
\hline & Coefficient & $\mathrm{R}^{2}$ & Coefficient & $\mathrm{R}^{2}$ & Coefficient & $\mathbf{R}^{2}$ \\
\hline \multicolumn{7}{|c|}{ Current Account and Capital Flows } \\
\hline Current Account $^{1}$ & $\begin{array}{l}-0.0005 \\
(-0.21)\end{array}$ & 0.02 & $\begin{array}{l}-0.0013 \\
(0.86)\end{array}$ & 0.03 & $\begin{array}{l}-0.0014 \\
(-1.02)\end{array}$ & 0.02 \\
\hline \multicolumn{7}{|l|}{ Capital Account } \\
\hline Net Bonds ${ }^{2}$ & $\begin{array}{l}-0.004 \\
(-1.97)\end{array}$ & 0.13 & $\begin{array}{l}0.00077 \\
(0.814)\end{array}$ & 0.03 & $\begin{array}{l}-0.00001 \\
(-0.03)\end{array}$ & 0.00 \\
\hline Govt. $^{3}$ & $\begin{array}{l}-0.005 \\
(-2.06)\end{array}$ & 0.15 & $\begin{array}{r}0.0003 \\
(0.264)\end{array}$ & 0.00 & $\begin{array}{l}-0.0008 \\
(-0.69)\end{array}$ & 0.01 \\
\hline Agency $^{4}$ & $\begin{array}{l}0.0002 \\
(0.01)\end{array}$ & 0.00 & $\begin{array}{l}0.0104 \\
(1.99)\end{array}$ & 0.16 & $\begin{array}{c}0.01 \\
(1.74)\end{array}$ & 0.06 \\
\hline Corporate $^{5}$ & $\begin{array}{l}-0.0012 \\
(-0.24)\end{array}$ & 0.00 & $\begin{array}{c}0.002 \\
(0.72)\end{array}$ & 0.02 & $\begin{array}{l}0.002 \\
(0.71)\end{array}$ & 0.01 \\
\hline Net Equities ${ }^{6}$ & $\begin{array}{r}0.005 \\
(0.55)\end{array}$ & 0.01 & $\begin{array}{l}0.0014 \\
(2.28)\end{array}$ & 0.19 & $\begin{array}{r}0.014 \\
(2.02)\end{array}$ & 0.08 \\
\hline $\mathrm{FDI}^{7}$ & & & $\begin{array}{r}0.003 \\
(0.59)\end{array}$ & 0.02 & $\begin{array}{l}0.0005 \\
(1.02)\end{array}$ & 0.04 \\
\hline \multicolumn{7}{|c|}{ Traditional underlying factors } \\
\hline $\begin{array}{l}\text { Long-term interest } \\
\text { rate differential }\end{array}$ & $\begin{array}{c}0.01 \\
(1.23)\end{array}$ & 0.06 & $\begin{array}{r}0.013 \\
(2.09)\end{array}$ & 0.17 & $\begin{array}{l}0.011 \\
(2.4)\end{array}$ & 0.11 \\
\hline $\begin{array}{l}\text { Short-term interest } \\
\text { differential }\end{array}$ & $\begin{array}{l}-0.001 \\
(-0.26)\end{array}$ & 0.00 & $\begin{array}{r}0.015 \\
(1.93)\end{array}$ & 0.15 & $\begin{array}{r}.001 \\
(0.61)\end{array}$ & 0.01 \\
\hline $\begin{array}{l}\text { Relative current } \\
\text { growth }\end{array}$ & $\begin{array}{c}1.46 \\
(0.59)\end{array}$ & 0.03 & $\begin{array}{c}1.44 \\
(0.78)\end{array}$ & 0.03 & $\begin{array}{c}1.41 \\
(0.96)\end{array}$ & 0.03 \\
\hline \multicolumn{7}{|c|}{ Alternative underlying factors } \\
\hline $\begin{array}{l}\text { Relative Stock } \\
\text { Returns }\end{array}$ & $\begin{array}{l}-0.55 \\
(2.4)\end{array}$ & 0.37 & $\begin{array}{l}-0.325 \\
(-3.16)\end{array}$ & 0.32 & $\begin{array}{c}-0.39 \\
(-3.87)\end{array}$ & 0.31 \\
\hline
\end{tabular}

Note: The equations regress the change in the logarithm of the bilateral exchange rate on a constant term and the contemporaneous value of the explanatory variable using quarterly data since 1988.

${ }^{1}$ The current account is the bilateral current account vis-à-vis the United States.

${ }^{2}$ Net bond flows are defined as US bond flows less foreign bond flows.

${ }^{3}$ Net government bond flows are defined as US government bond flows.

${ }^{4}$ Net agency bond flows are defined as US. Agency bond flows.

${ }^{5}$ Net corporate bond flows are defined as US corporate bond flows less foreign bond flows.

${ }^{6}$ Net equity flows are defined as US equity flows less foreign equity flows.

${ }^{7}$ Net FDI flows are based on BEA definition of net inflows and outflows. 
that the majority of cross-border M\&A flows are financed through share-swaps that have no immediate impact on the demand for currencies. ${ }^{14}$ Furthermore, even for cash purchases the foreign exchange implications are often limited, as the acquirer may already have cash holdings in the foreign currency or may issue debt in that currency. ${ }^{15}$ Another possible explanation, at least for smaller deals, is that the acquirer issues debt in its home currency where its client base is well established, but uses interest rates swaps to hedge its home currency exposure.

The movement of the euro-dollar exchange rate is significantly correlated with the long-term interest rate differential. In fact, its explanatory power is similar to that of net equity flows. The statistical evidence on the remaining traditional explanatory variables shows that these variables contribute little to the explanation of the movement of the exchange rate. The relative growth differentials between U.S. and Europe also do not appear to be important in explaining the movement of the euro-dollar rate.

\section{Econometric Results for the Yen}

The results for the yen are different from those for the euro as shown in Table 2. Other than long-term interest rate differentials, which are positive and marginally significant, most of the other variables do not seem to explain movement in the yen. The one exception is bond flows that are reported to be statistically significant but of the wrong sign, owing possibly in part to continual Japanese purchases of US bonds even as the yen weakened. ${ }^{16}$ In the meantime, the equity flow variables, which were so important in the earlier analysis of the euro-dollar exchange rate, do not seem to matter for the yen dollar rate.

${ }^{14}$ See, for example, Morgan Stanley Dean Witter, November 2000.

${ }^{15}$ However, there may be a delayed response as investors adjust their portfolios for an effective foreign currency exposure following a takeover and acquirers adjust the composition of their currency holdings.

${ }^{16}$ Movements in the long-term interest rate differential clearly account for some of the movement in the yen rate. For example, Japanese long-term interest rates declined significantly over the 1995-97 period, reflecting an easing of Japanese monetary policy. These lower rates in turn contributed to a significant widening of yield spreads and the yen weakened accordingly. 
Table 2. Explaining Bilateral Exchange Rate Movements: Japan

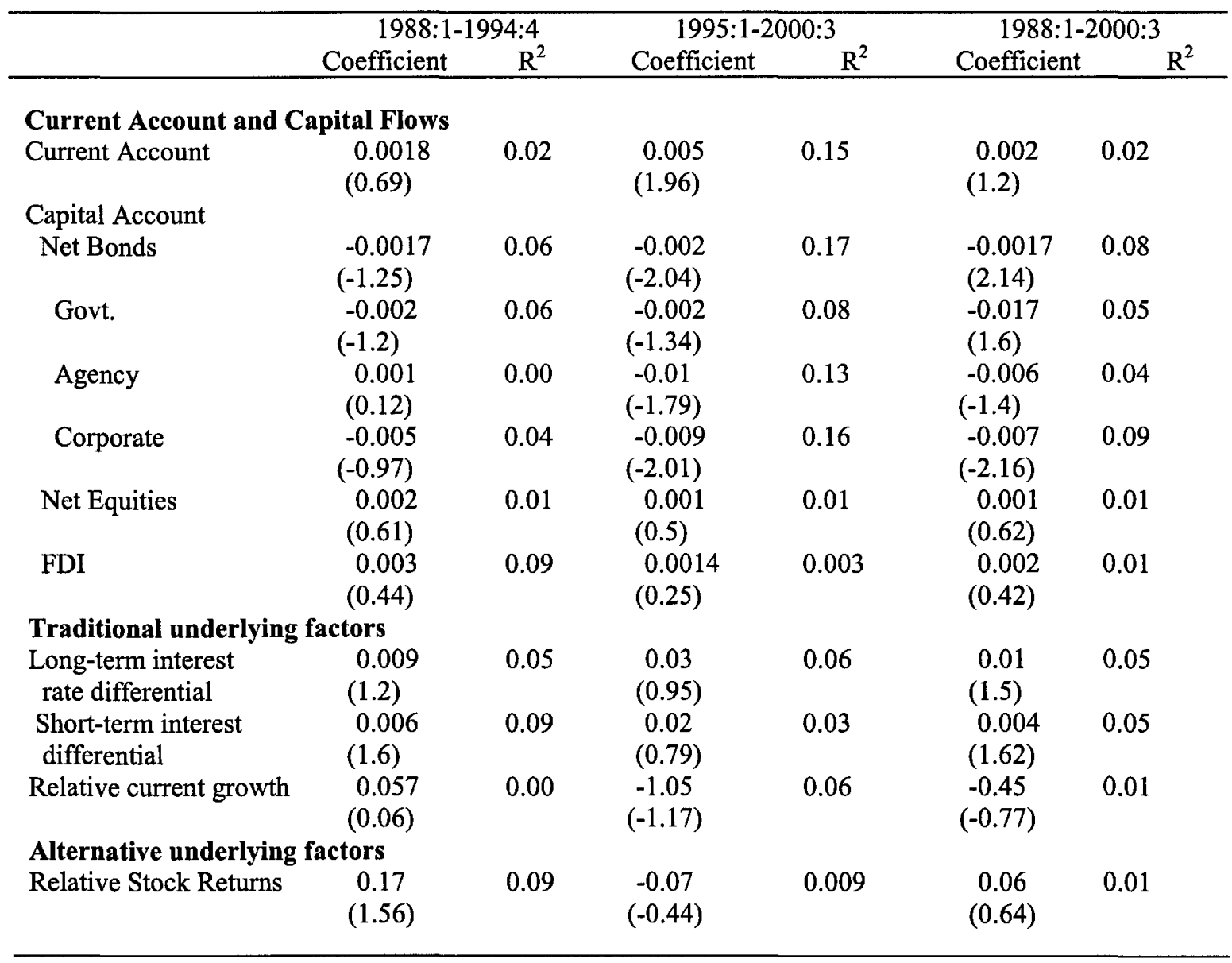

\section{Robustness TeSTS}

There are a number of limitations to the exercise described above. This section tries to address them and assess the robustness of the results by examining other bilateral European exchange rates, by testing multilateral data on current accounts and capital flows, and by considering the explanatory power of expected relative growth. ${ }^{17}$

${ }^{17}$ A fourth limitation to the analysis relates to the statistical methods used. A correct approach would be to model both exchange rates and capital flows simultaneously as both variables are endogenous. This approach was not considered as exchange rates are notoriously difficult to model and introducing a multi-equation model would draw attention away from the focus of this paper-investigating the role of capital flows in explaining the movements of the euro and the yen. 
The first potential problem relates to interpreting the empirical results based on aggregating data for individual euro area countries. As a robustness check on euro area results, bilateral versions of the regressions were also estimated with similar results. Table 3 shows the results for the German mark and the French franc in general, they are similar to the results reported in Table 1 for the entire euro area. In particular, for both France and Germany equity flows are positive and statistically significant.

Table 3. Explaining Bilateral Exchange Rate Movements: Germany and France

\begin{tabular}{lcccc}
\hline \multicolumn{2}{c}{$\begin{array}{c}\text { Germany } \\
\text { Coefficient } \\
\text { (t-value) }\end{array}$} & $\mathrm{R}^{2}$ & $\begin{array}{c}\text { Coefficient } \\
\text { (t-value) }\end{array}$ & $\mathrm{R}^{2}$ \\
\hline Net Gov't Bonds/Notes & -0.0019 & 0.03 & 0.0005 & 0.00 \\
& $(-1.1164)$ & & $(0.1077)$ & 0.01 \\
Net Agency Bonds & 0.0173 & 0.03 & -0.0280 & \\
& $(1.1301)$ & & $(-0.6092)$ & 0.07 \\
Net Corporate Bonds & 0.0102 & 0.01 & 0.0268 & 0.13 \\
& $(0.9659)$ & & $(1.8613)$ & 0.16 \\
Net Equities & 0.0053 & 0.10 & 0.0147 & $(2.6568)$ \\
& $(2.2698)$ & & 0.0037 & $(2.1516)$ \\
Net FDI & & & \\
& -0.0008 & 0.02 & & \\
TSample period for net FDI regressions 94:1 to 00:3 since BEA data is only available from 94:1.
\end{tabular}

A second problem relates to identifying bilateral capital flows some of which go through major financial centers making it more difficult to identify significant relationships. Consequently, as a robustness check on the bilateral results, multilateral versions of the regressions (where flows to and from financial centers are netted out) have been estimated, also with broadly similar results. Tables 4 and 5 report results where we substituted the bilateral data with multilateral data on current accounts, the various components of capital flows, and multilateral exchange rate for Germany and Japan. ${ }^{18}$

Table 4 shows the results of the individual regressions for Germany, where the dependent variable is log change in the trade weighted multilateral exchange rate and is defined as domestic currency per dollar (i.e. an increase denotes an appreciation of the

\footnotetext{
${ }^{18}$ Data on Germany is used rather than on the Euro area for this robustness test, owing to the difficulty of aggregating the data.
} 
domestic currency and a depreciation of the trade partners' currency), for the periods 1980:1 to $1990: 1$ and 1990:1 to $2000: 3$. The sample is split to test for shifts in the factors explaining exchange rate movements from the 1980 to the 1990s.

Table 4. Explaining Movements in the Multilateral Exchange Rate: Germany

\begin{tabular}{|c|c|c|c|c|}
\hline \multirow[t]{2}{*}{ Sample period } & \multicolumn{2}{|c|}{ 1980:1-1990:1 } & \multicolumn{2}{|c|}{ 1990:1-2000:3 } \\
\hline & $\begin{array}{c}\text { Coefficient } \\
\text { (t-value) }\end{array}$ & $\mathbf{R}^{2}$ & $\begin{array}{c}\text { Coefficient } \\
\text { (t-value) }\end{array}$ & $\mathbf{R}^{2}$ \\
\hline Current account & $\begin{array}{l}-0.00145 \\
(2.12)\end{array}$ & 0.19 & $\begin{array}{l}-0.00024 \\
(0.18)\end{array}$ & 0.00 \\
\hline Net portfolio flows & $\begin{array}{l}-0.00391 \\
(1.28)\end{array}$ & 0.14 & $\begin{array}{l}-0.00140 \\
(1.98)\end{array}$ & 0.09 \\
\hline Net foreign direct investment & $\begin{array}{l}0.00843 \\
(2.02)\end{array}$ & 0.19 & $\begin{array}{l}0.00013 \\
(0.12)\end{array}$ & 0.00 \\
\hline Basic Balance 1 & $\begin{array}{l}-0.00133 \\
(1.84)\end{array}$ & 0.17 & $\begin{array}{l}-0.00001 \\
(0.01)\end{array}$ & 0.00 \\
\hline Basic Balance 2 & $\begin{array}{l}-0.00183 \\
(2.39)\end{array}$ & 0.22 & $\begin{array}{l}-0.00217 \\
(2.54)\end{array}$ & 0.14 \\
\hline Real growth differential & $\begin{array}{l}-0.03947 \\
(0.18)\end{array}$ & 0.10 & $\begin{array}{l}-0.03776 \\
(0.38)\end{array}$ & 0.00 \\
\hline Consumer prices & $\begin{array}{l}-0.63647 \\
(1.57)\end{array}$ & 0.15 & $\begin{array}{l}0.16285 \\
(0.49)\end{array}$ & 0.01 \\
\hline Stock prices & $\begin{array}{l}-0.00362 \\
(0.11)\end{array}$ & 0.11 & $\begin{array}{l}0.05423 \\
(1.88)\end{array}$ & 0.08 \\
\hline Long interest rate differential & $\begin{array}{l}-0.00343 \\
(1.70)\end{array}$ & 0.16 & $\begin{array}{l}-0.00801 \\
(3.39)\end{array}$ & 0.22 \\
\hline Short interest rate differential & $\begin{array}{l}-0.00546 \\
(-3.91)\end{array}$ & 0.35 & $\begin{array}{l}-0.00166 \\
(2.33)\end{array}$ & 0.12 \\
\hline
\end{tabular}

Note: All right-hand side variables are calculated relative to the United States. Variables are as defined above and Basic Balance 1 is defined as current account plus FDI and Basic Balance 2 is defined as current account plus FDI plus portfolio flows.

The first row reports the results for the current account. It shows that in the period 1980 to 1990 the current account was significant in explaining exchange rate movements. The negative sign suggests the expected relationship; when the domestic current account surplus increases it will be associated with an appreciation of the domestic currency relative to its trade partners. The second line displays the relationship between net portfolio flows and the multilateral exchange rate. An increase in the portfolio flows into the domestic country leads to an appreciation of the domestic currency. For the period 1980 to 1990 this relationship is insignificant but for the period 1990 to 2000 the coefficient becomes marginally significant with the expected negative sign; portfolio flows out of Germany led to a depreciation of the effective exchange rate. In others words, the multilateral data confirms the results found above using the bilateral data. It is worth noting that the short interest rate differential has been significant in both periods and the long has become significant in the last period. 
The results for Japan (Table 5) are somewhat different from above. They suggest that current account and portfolio flows were important in the period from 1980 to 1990 , while they are not statistically significant since 1990 . This holds true for all variables; none of these variables are significant explanatory factors of developments of the Japanese yen in this period, whereas for the period from 1980 to 1990 interest rate differentials were also significant. These findings for Japan seem in line with the results found above using the bilateral data. The results suggest that it is quite difficult to model the Japanese yen; especially since 1990. It appears that interest rate differentials work best, but they are only marginally significant.

Table 5. Explaining Movements in the Multilateral Exchange Rate: Japan

\begin{tabular}{|c|c|c|c|c|}
\hline \multirow[t]{2}{*}{ Sample period } & \multicolumn{2}{|c|}{ 1980:1-1990:1 } & \multicolumn{2}{|c|}{ 1990:1-2000:3 } \\
\hline & $\begin{array}{c}\text { Coefficient } \\
\text { (t-value) }\end{array}$ & $\mathrm{R}^{2}$ & $\begin{array}{c}\text { Coefficient } \\
\text { (t-value) }\end{array}$ & $\mathrm{R}^{2}$ \\
\hline Current account & $\begin{array}{l}0.00589 \\
(2.03)\end{array}$ & 0.14 & $\begin{array}{l}0.00438 \\
(0.74)\end{array}$ & 0.03 \\
\hline Net portfolio flows & $\begin{array}{l}-0.00781 \\
(2.60)\end{array}$ & 0.19 & $\begin{array}{l}0.00322 \\
(0.98)\end{array}$ & 0.04 \\
\hline $\begin{array}{l}\text { Net foreign direct } \\
\text { investment }\end{array}$ & $\begin{array}{l}0.01501 \\
(1.47)\end{array}$ & 0.09 & $\begin{array}{l}-0.00659 \\
(1.00)\end{array}$ & 0.04 \\
\hline Basic Balance 1 & $\begin{array}{l}0.00767 \\
(2.64)\end{array}$ & 0.19 & $\begin{array}{l}-0.00072 \\
(0.14)\end{array}$ & 0.01 \\
\hline Basic Balance 2 & $\begin{array}{l}0.00115 \\
(0.19)\end{array}$ & 0.05 & $\begin{array}{l}0.00360 \\
(0.98)\end{array}$ & 0.03 \\
\hline $\begin{array}{l}\text { Real growth } \\
\text { differential }\end{array}$ & $\begin{array}{l}-0.70671 \\
(1.23)\end{array}$ & 0.08 & $\begin{array}{l}-0.92360 \\
(1.44)\end{array}$ & 0.06 \\
\hline Consumer prices & $\begin{array}{l}1.96805 \\
(1.16)\end{array}$ & 0.08 & $\begin{array}{l}1.24141 \\
(0.72)\end{array}$ & 0.03 \\
\hline Stock prices & $\begin{array}{l}0.14081 \\
(0.99)\end{array}$ & 0.07 & $\begin{array}{l}0.03589 \\
(0.36)\end{array}$ & 0.02 \\
\hline $\begin{array}{l}\text { Long interest rate } \\
\text { differential }\end{array}$ & $\begin{array}{l}0.01304 \\
(2.08)\end{array}$ & 0.14 & $\begin{array}{l}0.01025 \\
(1.50)\end{array}$ & 0.07 \\
\hline $\begin{array}{l}\text { Short interest rate } \\
\text { differential }\end{array}$ & $\begin{array}{l}0.01084 \\
(3.65)\end{array}$ & 0.29 & $\begin{array}{l}0.00730 \\
(1.35)\end{array}$ & 0.06 \\
\hline
\end{tabular}

Note: All right-hand side variables are calculated relative to the United States. Variables are as defined above and Basic Balance 1 is defined as current account plus FDI and Basic Balance 2 is defined as current account plus FDI plus portfolio flows.

Another issue that has been hitherto ignored is that the sum of the current and capital accounts (including changes in official reserves) are zero by definition, therefore movement in one part of the accounts must induce an offsetting movement elsewhere, presumably resulting from changes in the exchange rate (the underlying price). Because of this accounting relationship a current or capital account flow, which explains exchange rate movements cannot be said to be causing the resulting movements in exchange, rates. Rather, both are (presumably) being driven by the same underlying factor. The type of current or 
capital account flows that correlate with exchange rate movements could help identify which underlying economic factors are likely to be important. For example if net equity flows help to explain movements in the exchange rate of the euro against the U.S. dollar, this suggests that differences in expected real growth may be important, an interpretation that can be further examined by looking at a supplementary regression with relative expected growth rates.

Table 6 reports supplemental regressions, which explore this hypothesis, using bilateral exchange rates and expected growth forecasts from the Consensus Forecast (monthly data). ${ }^{19}$ Owing to aggregation problems the German mark and forecasts for Germany replaces the euro and euro area forecast. The results in Table 6 confirm that for the latter period (1995-2000) the expected growth differential between the United States and Germany contributed significantly to explaining the movements in the exchange rate. For Japan, this is not the case, which is consistent with our earlier findings that more traditional factors explain movements in the yen.

Table 6. Bilateral Exchange Rate Movements and Expected Growth Differential (US minus foreign)

\begin{tabular}{lcccccc}
\hline & & $1990: 2-1994: 12$ & & \multicolumn{3}{c}{$1995: 1-2001: 1$} \\
& Constant & Coefficient & $\mathrm{R}^{2}$ & Constant & Coefficient & $\mathrm{R}^{2}$ \\
\hline Germany & -0.0013 & 0.0003 & 0.0004 & -0.0048 & 0.0160 & 0.0827 \\
\multirow{3}{*}{ Japan } & $(0.3303)$ & $(0.1575)$ & & $(1.0962)$ & $(2.5305)$ & \\
& -0.0068 & -0.0009 & 0.0048 & 0.0093 & -0.0041 & 0.0205 \\
& $(1.9783)$ & $(0.5210)$ & & $(1.3258)$ & $(1.2202)$ & \\
\hline
\end{tabular}

\section{Summary ANd Policy Implications}

This paper has tried to shed some light on a significant puzzle in international currency markets today: how, despite a record current account imbalance, the U.S. dollar has reached all time highs, while the euro has weakened significantly from its inception against all major currencies, and the Japanese yen has after falling sharply from its peak in April 1995, rebounded only to fall back again. A key element in the puzzle appears to be the sharp increase in large capital flows among the three currency areas, apparently driven by a number of factors in addition to interest differentials. Large inflows into the U.S. equity markets and direct investment flows have financed the current account deficit and allowed the dollar to remain strong. Conversely, large and initially unanticipated outflows from the euro area appear to account for a substantial part of its fall and persistent weakness. The main

${ }^{19}$ The growth forecasts are derived from the private sector "Consensus" forecasts for the U.S., Japan and the Euro area. We utilized the consensus projections in the raw form and in addition, a simple weighting scheme was also used whereby projections made in the near months are given greater weight than projections made in distant months. 
contribution of this paper is to document these flows and obtain some initial estimates of their impact on exchange rates. There are five key findings of the paper:

First, it illustrates how over the past five years or so, the United States has been the recipient of very large net capital inflows. In absolute terms, the magnitude of these inflows dwarfs anything ever seen in the world economy over a comparable period.

Second, there has been a perceptible shift in the origin and composition of flows, with flows from Europe moving much more into equities, while Japanese investors have continued to purchase U.S. government bonds with little increase in the net flow to equities. While net flows into U.S. government bonds have gradually contracted over the $1990 \mathrm{~s}$, the net flows into U.S. stocks have risen by a factor of 12 since 1995 . The rapid expansion in international equity flows has also coincided with a boom in cross-border mergers and acquisitions. Bilateral net flows into U.S. equities from the euro area have increased dramatically, while there is little evidence of a similar shift for Japan. A similar pattern holds for mergers and acquisitions, with almost two-fifths of the companies originating deals from the euro area and a significant share in technology sectors.

Third, an analysis of bilateral exchange rates and current account balances showed that the latter are generally not significant for explaining exchange rate movements. The only exception to this is for Japan in the late 1990s where an increase in the Japanese current account surplus relative to the United States appears to have led to upward pressure on the yen against the US dollar.

Fourth, analyzing the relationship between exchange rates and portfolio flows suggests that in the second half of the $1990 \mathrm{~s}$, in the case of the euro area, there was a strong relationship between exchange rate movements and equity flows, with an increase in equity flows to the United States associated with a clear depreciation of the euro (or synthetic euro prior to 1999) vis-à-vis the US dollar. However, such a clear relationship is not seen in the case of Japan. Foreign direct investment, which includes mergers and acquisitions, appears not to have played an important role in euro weakness, possibly because the majority of cross-border M\&A flows are financed through share-swaps that have no immediate impact on the demand for currencies.

Fifth, the results for changes in the exchange rate between the yen and the dollar since 1988 are strikingly different from those for the euro, and suggest an important role for longterm interest rate differentials and relative current account positions while equity flow variables appear not to matter for the yen dollar rate. A number of supplementary tests using multilateral exchange rates tend to support the results obtained above.

The differences between the determinants of the euro vis-à-vis those for the yen merit attention: in part, the simple diversification motive may provide an explanation. With the advent of the euro, returns across the euro area stock markets have become more correlated. As a result, euro area investors wishing to diversify their portfolios will tend to move some of their original intra-euro area investments outside of the region, consistent with the recent 
increase in net equity investment from the euro area to the rest of the world. As there has been no shift in underlying conditions in Japan, no similar impact would be seen on the yen. This explanation suggests that the weakness of the euro may not be reversed quickly or significantly, as the stock adjustment driven by the desire for portfolio diversification may be only achieved gradually.

An alternative explanation is that risk-neutral investors in the euro area sought to maximize their returns, and invested in the U.S. equity markets because of perceived higher returns. In Japan, however, particular conditions may have made equity holders (which are mainly financial institutions) considerably more risk averse. Because of the fragility of the Japanese financial system, banks or insurance companies may have been more focused on their capital base than maximizing high rates of return. This explanation implies that euro weakness and dollar strength reflect perceptions of growth differentials between the euro area and the United States, perceptions that could potentially change rapidly, although they appear not to be doing so despite the recent sharp downgrading of near-term U.S. economic prospects vis-à-vis those of the euro area. Nevertheless, there is likely a proportion of euro area outflows that would be repatriated if returns abroad turned out to be disappointing, while financial sector fragility may also help explain the continued appetite from Japan for U.S. government securities.

In other words, to date the high reliance of the US on capital flows to finance the current account deficit has not been a problem, in part given the weak expected returns on investment overseas. But if expectations of relative rates on return on assets, particularly in the euro area, were to increase, competition for global capital could make markets sensitive to the large U.S. current account imbalance and lead to substantial and rather abrupt changes in major currency exchange rates. 


\section{REFERENCES}

Aranda-Hassel et al, CFSB Euro Area Weekly, various issues.

Bailey, Andrew, Stephen Millard, and Simon Wells, 2001, "Capital Flows and Exchange Rates," Bank of England Quarterly Bulletin, Autumn, pp 310-318.

Chinn, Menzie and Ron Alquist, 2000, "Tracking the Euro's Progress," forthcoming International Finance.

Clostermann, Jorg and Bernd Schnatz, 2000, "The Determinants of the Euro-Dollar Exchange Rate," Economic Research Group of the Deutsche Bundesbank, Discussion Paper, 2/00 (May).

De Grauwe, Paul, 2000, "The Euro-Dollar Exchange Rate In Search of Fundamentals," unpublished paper, University of Leuven.

Deutsche Bank, Global FX Outlook and Strategy - Special Edition, November 10, 2000, pp. 21-23, and Deutsche Bank, Global FX Outlook and Strategy, December 1, 2000, pp. 16-18.

Edison, Hali and Torsten Sløk, 2001a, "Wealth Effects and the New Economy," IMF Working Paper 01/77 (Washington: International Monetary Fund). ,2001b, "New Economy Stock Valuations and Investment in the 1990s," IMF Working Paper 01/78 (Washington: International Monetary Fund).

Goldman Sachs, European Weekly Analyst, various issues. , US Weekly Analyst, various issues.

Greenspan, Alan, 1998, "Is There a New Economy?" Speech at the Haas Annual Business Faculty Research Dialogue, University of California, Berkeley, September 4.

Greenspan, Alan, 2000, "Structural Changes in the Economy and Financial Markets," Speech at the America's Community Bankers Conference, New York, New York, December $5,2000$.

Isard, Peter, 1995, Exchange Rate Economics (Cambridge: Cambridge University Press).

JP Morgan, Global Data Watch, various issues.

Krugman, Paul, 1988, “Exchange Rate Instability,” (Cambridge, Massachusetts: MIT Press). 
Krugman, Paul, 1997, “The Euro: Beware of What You Wish For,” Fortune, December 1998.

Kumar, Manmohan, S., 1996, "Inward Foreign Direct Investment in the UK." International Monetary Fund (SM/96/254) (October).

Lehman Brothers, Global Foreign Exchange Strategies, various issues.

Meredith, Guy, 2001, “Why Has the Euro Been So Weak”, IMF Working Paper, WP/01/155, (Washington: International Monetary Fund).

Meese, Richard and Kenneth Rogoff, 1983, "Empirical Exchange Rate Models of the Seventies: Do They Fit Out of Sample?" Journal of International Economics, pp. 3-24.

Morgan Stanley Dean Witter, Currency Strategy and Economics, various issues

Taylor, Mark P., 1995, “The Economics of Exchange Rates,” Journal of Economic Literature 33 , pp 13-47.

Tille, Cedric, Nicolas Stoffels, and Olga Gorbachev, 2001, "To What Extent Does Productivity Drive the Dollar?" Federal Reserve Bank of New York Current Issues in Economics and Finance (August), pp 1-6. 